\title{
Investigation of fluid flow structure in open type cavity under stationary and pulsatile flow conditions
}

\author{
Paulius Vilkinis, \\ Mantas Valantinavičius, \\ Nerijus Pedišius \\ Laboratory of Heat Eqiupment \\ Research and Testing, \\ Lithuanian Energy Institute, \\ Breslaujos str. 3, \\ LT-44403 Kaunas, Lithuania \\ E-mail paulius.vilkinis@lei.lt
}

A study of fluid flow in structured channels plays an important role in solving most fluid dynamics problems. The knowledge of the flow structure in separate cavities can be used to intensify mixing in microreactors and microelectrochemical systems (MEMS) as well as to increase heat transfer in heat sinks. Besides, knowledge about fluid flow in micro cavities could be useful to mitigate the symptoms of aneurysms. In this study, a 2D micro-particle image velocimetry ( $\mu \mathrm{PIV}$ ) system was used to investigate water flow in an open-type microcavity located in a straight, square cross-section $\left(0.5 \times 0.5 \mathrm{~mm}^{2}\right)$ microchannel. Two identical micro cavities of the same cross-section as the main channel and the depth of $1 \mathrm{~mm}$ are oppositely located in the middle part of the channel. Because of symmetry, the flow structure of the primary vortex was investigated in only one cavity. Measurements were carried out in different planes over the entire height of the cavity at Reynolds number in the range from 100 to 3000 . The flow in the channel was stationary and pulsating.

Results indicate that flow in the cavity is three-dimensional. This is confirmed by velocity profile shape changes in its different transversal planes. In addition, it is determined that flow structure in the cavity depends on flow regime and flow pulsation characteristics. Velocity distribution shows that in the transverse direction there is the minimum velocity zone corresponding to the centre of the primary vortex generated by the channel flow, also the same zone is observed along the cavity in its axial plane. At low Re, such velocity distribution occurs in pulsating flow earlier than in the case of stationary flow. With increasing Re, velocity distribution in pulsating flow flattens out also more. It means that disturbed flow in the channel accelerates the formation of a stable flow structure in the cavity.

Key words: microfluidics, flow in microchannel, micro-particle image velocimetry, micro cavity

\section{INTRODUCTION}

Investigations of flows over cavities, backward facing steps and obstacles help to gain full understanding of flow dynamics and physics. Flows in a structured microchannel play an important role in such engineering problems like mixing in microreactors, microelectrochemical systems [1], heat transfer intensification in heat sinks [2] and mitigation of blood flow impact in aneurysms [3].

Chen and Hung studied vortex structure of two-dimensional flow in open-type cavities [4]. Cavities aspect ratio varied from 0.1 to 7 , and flow regime from laminar to fully turbulent. Results showed that vortices centre position in a deep rectangular cavity depends on Re number and 
aspect ratio. When Re is very small, vortex structure in the cavity is symmetrical and it changes with Re number increasing. Faure et al. investigated fluid flow over an open cavity with aspect ratio varying between 0.5 and 2 and Reynolds number in the range of $1150 \leq \mathrm{Re} \leq 10670$ [5]. Smoke was used for flow visualization. The authors concluded that three-dimensional spanwise structures are developing in cavities. The rotation of primary and secondary vortices generates flow between them that can develop only in the spanwise direction. Spanwise vortices generate large advection velocity and centrifugal instabilities in flow [6]. Beaudoin et al. observed three-dimensional flow structures in the spanwise direction in flow over a backward-facing step using the particle image velocimetry system [7]. It is considered these transverse longitudinal vortices are induced by recirculating flow behind the reattachment point.

In this study, stationary and pulsatile flow in a microchannel with an open-type micro cavity is investigated. The task of this research is to investigate flow and vortex structures in a cavity under both flow conditions and restore the spatial structure of the vortex from two-dimensional velocity profiles.

\section{TECHNIQUE}

Flow vector fields and velocity profiles were obtained by the micro-particle image velocimetry system ( $\mu \mathrm{PIV}) . \mu \mathrm{PIV}$ is an optical method used to measure fluid motion in small-diameter channels. Fluorescent tracer particles are illuminated by a laser sheet. Excited particles generate a fluorescence signal, which is collected by a CCD camera. Several pictures are taken within a known period of time. Knowing the time separating two successive particle images and displacement of the particle within that time, particle velocity is calculated.

The $\mu$ PIV system provided by Dantec Dynam$i c s$ consists of a double pulsed neodymium-doped yttrium aluminum garnet (Nd:YAG) laser, laser control system LPU 450, FlowSense EO CCD camera providing an image field of $2048 \times 2048$ pixels mounted on the inverted Leica DM ILM microscope. Deionized water flow rates from $0.001 \mu \mathrm{l} / \mathrm{h}$ to $7635 \mathrm{ml} / \mathrm{h}$ in the microchannel are formed by a syringe pump WPI AL4000 (World Precision Instruments). Pulsatile flow is generated with OB1 MK3 microfluidic flow control system provided by Elveflow. Tracer particles (Invitrogen) added to water were $1 \mu \mathrm{m}$ in diameter. Delay between two laser pulses depends on water flow rate. Slow-moving particle displacement can be captured with long pulse separation time, while fast-mowing particles require shorter time between pulses. Therefore, different delay was used to measure the velocity in the axial plane of the channel and near walls.

Velocities were calculated by summing longitu$\operatorname{dinal}\left(v_{x}\right)$ and transversal $\left(v_{y}\right)$ velocity components:

$$
v=\sqrt{v_{x}^{2}+v_{y}^{2}} .
$$

It should be kept in mind that only total velocities are presented in Figures below. In addition, velocity direction is changing at the centre of the vortex, which is not presented in Figures.

Experiments were conducted in a microchannel manufactured in a transparent polymer chip. Microchannel cross-section is of square shape with dimensions of $0.5 \times 0.5 \mathrm{~mm}^{2}$. Microchannel total length is $63 \mathrm{~mm}$. In the central part, at a distance of $40 \mathrm{~mm}$ from the inlet, the microchannel has two oppositely located micro cavities. The cross-section of cavities is square to a depth of $0.75 \mathrm{~mm}$, and the bottom of the rounded radius $r=0.25 \mathrm{~mm}$. The scheme of the investigated microchannel is presented in Fig. 1.

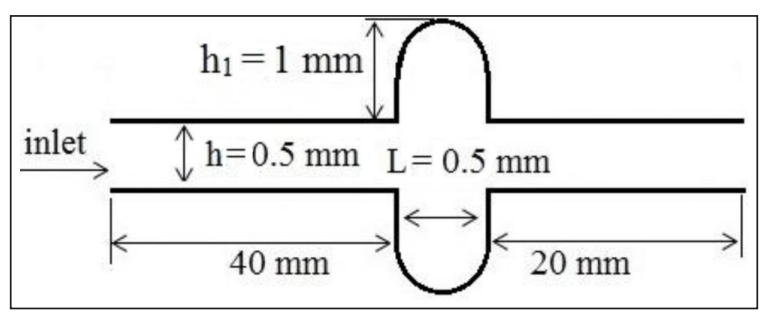

Fig. 1. Scheme of investigated microchannel with two micro cavities on the opposite walls

\section{RESULTS}

\section{Stationary flow over open cavity}

The velocity vector maps in an open-type cavity at different flow regimes and measurement planes are presented in Fig. 2. A thick blue arrow on the lid of the cavity shows flow direction in the main channel. Thin black arrows represent flow direction in 


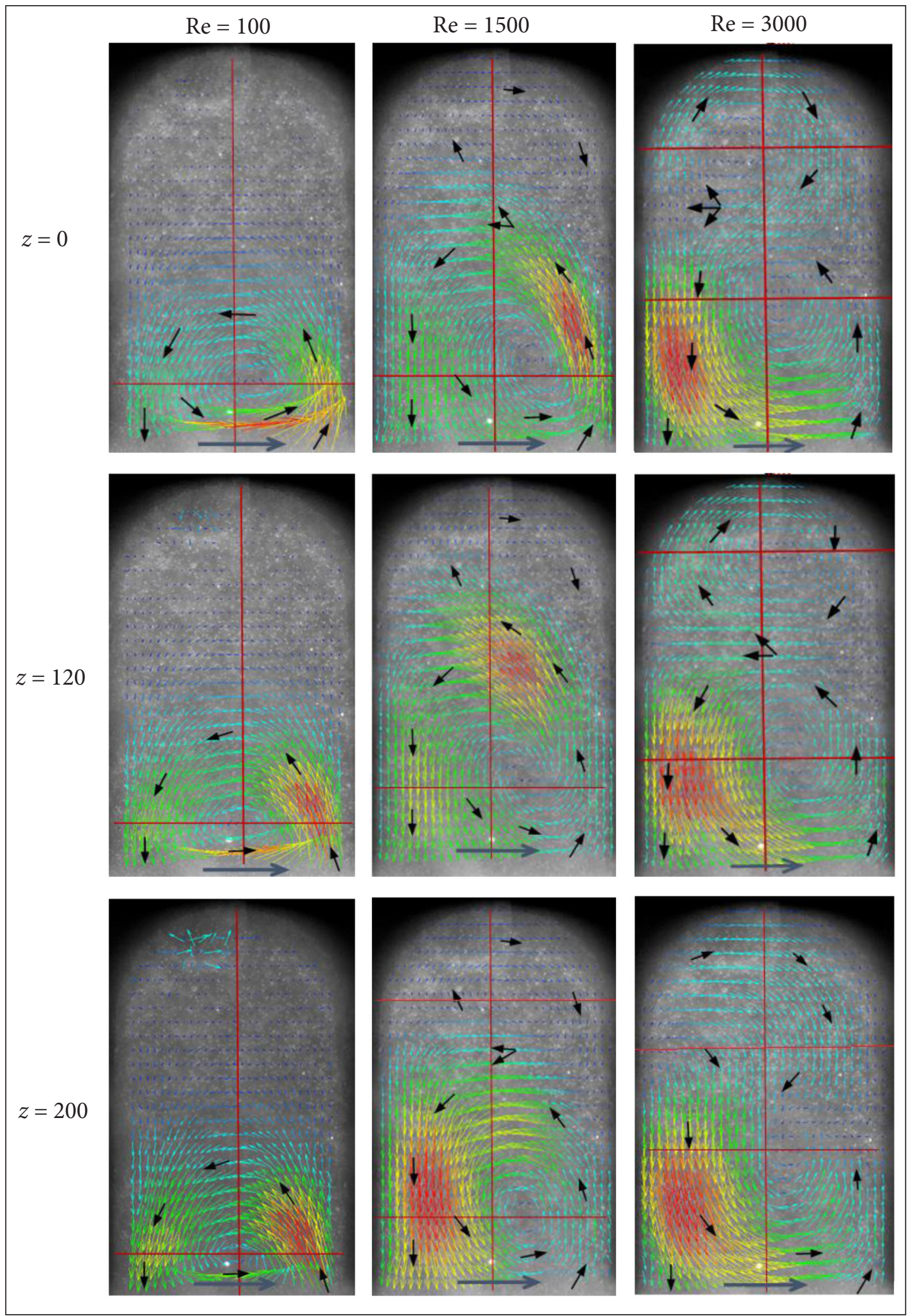

Fig. 2. Velocity vector maps in an open-type cavity at different Reynolds numbers and measurement planes

the cavity. Vertical and horizontal red lines indicate the cross-sections where velocity profiles were measured. As can be seen from $2 \mathrm{D}$ images of velocity vectors presented in Fig. 2, the structure of vortices in the cavity significantly depends on $\mathrm{Re}_{\mathrm{Dh}}$. In laminar flow $\left(\mathrm{Re}_{\mathrm{Dh}}=100\right)$, 
one vortex is observed in the cavity, the centre of which is almost on the cavity axis, but distant from the cavity lid and located at $y / h_{1} \sim 0.15$. The secondary vortex at the bottom of the cavity is not observed. The values of relative velocity $v / v_{o}$ (here, $v_{o}$ - velocity in the channel) in the cavity axis, presented in Fig. 3, demonstrate that the velocity of fluid circulation in the cavity is very small as compared to the velocity in the channel. Its minimal value approximately reflects the position of vortex centre. The largest velocity in the cavity axis is observed at the cavity lid and along $y / h_{1} \sim 0.25$, from which going deep into the cavity, velocity gradually reduces. Depending on the measuring plane, the largest velocity (red coloured vectors in Fig. 2) in the cavity middle plane $(z=0)$ is observed at the interface between the main flow in the channel and flow in the cavity. Approaching the wall of the cavity, $z=120-200$, the maximum velocity is shifted to the forward-facing wall of the cavity.

As $\mathrm{Re}_{\mathrm{Dh}}$ reaches the value of 1500 , the main vortex is stretched in the direction of flow, its asymmetry increases, and the position of the greatest velocity in the middle plane is located near the forward-facing step. Also, the signs of the formation of the second vortex with the opposite rotation direction at the bottom of the cavity become apparent. The whole structure obtains the form of eight. At $z=120$, maximum velocity is located at interface between main and secondary vortices. At the near-wall region, $z=200$, the greatest velocity shifts to the backward-facing wall of the cavity and enters the main flow.

Upon transition of flow in the channel into the turbulent flow regime $\left(\mathrm{Re}_{\mathrm{Dh}}=3000\right)$, in the cavity, besides the main vortex, a strong secondary vortex is formed at the bottom of the cavity. It is seen that the flow drawn into the cavity reattaches to the front vertical wall of the cavity and at the reattachment zone splits into two parts, one of which moves towards the flow in the channel forming a primary vortex, and the other one moves towards the bottom of the cavity and forms a secondary vortex with the opposite direction of rotation. The greatest velocity remains at the backward-facing wall of the cavity in the whole height of the cavity. Velocity minima in the cavity axis along $y / h_{1} \sim 0.2$ and 0.7 (Fig. 3, curve 3 ) corresponds to the centre position of the main and secondary vortices, and maximum along $y / h_{1} \sim 0.6$ to the division of these vortices. Volumes taken by both vortices in the cavity even out.

Figure 4 presents the values of relative velocity based on the cavity length in the axial plane passing through the centres of the main (a) and secondary (b) vortices parallel to the channel wall. Thus, these values indicate velocities at which the fluid with regard to the centre

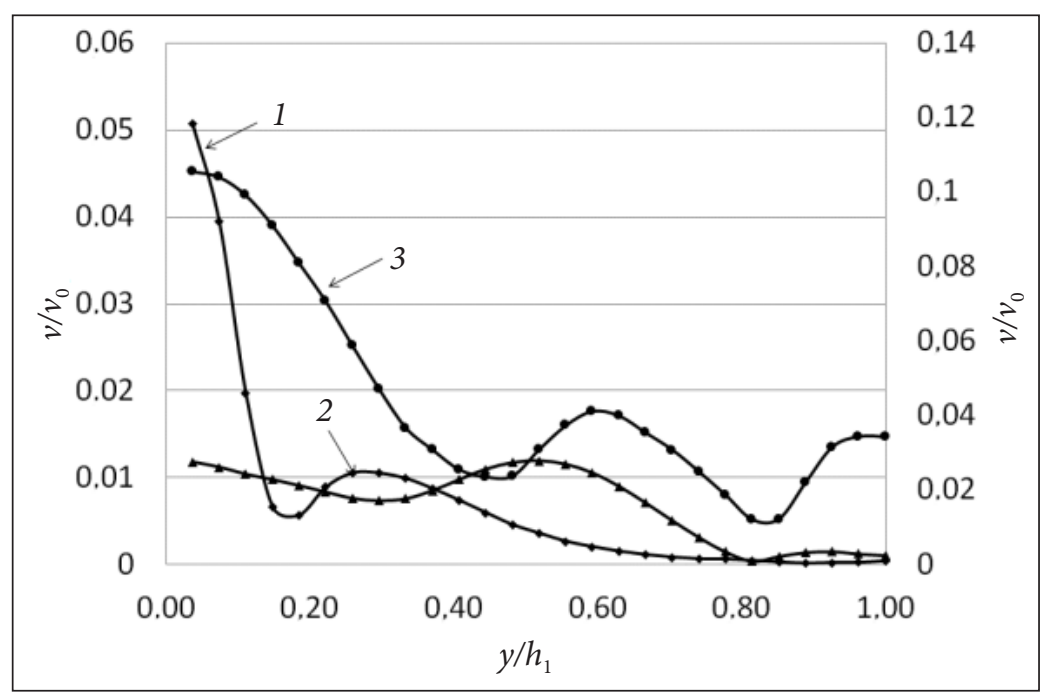

Fig. 3. Relative velocity values in the cavity axis based on its depth: 1,2 , and $3-\operatorname{ReDh}=100$ $\left(v / v_{0}\right.$ values on the right-sided vertical axis), 1000 , and $2500 . y / h_{1}$ value 0 indicates the location of the cavity lid, and $y / h_{1}=0$ indicates the bottom of the cavity 


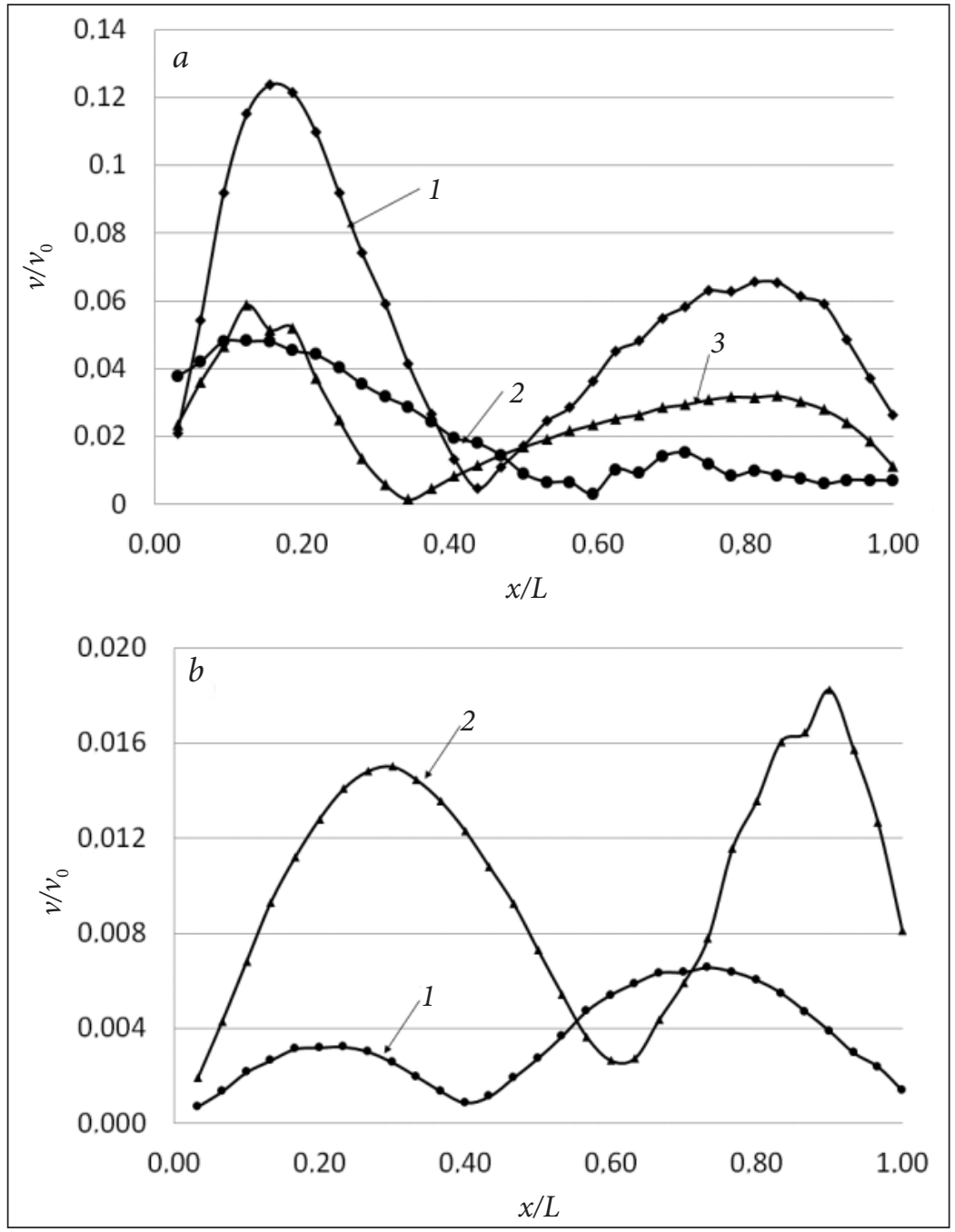

Fig. 4. Relative velocity values at the axial plane level of the channel corresponding to ( $a$ ) the main and (b) secondary vortex centres: $\mathrm{a}: 1,2$, and $3-\mathrm{Re}_{\mathrm{Dh}}=100,1500$, and 3000; b: 1 and $2-\operatorname{Re}_{\mathrm{Dh}}=1500$ and $2500 . x / L$ value 0 indicates the edge of the backward-facing wall, and $x / L$ value 1 indicates the forward-facing wall of the cavity

of the main vortex (Fig. 3a) streams towards the cavity bottom when $x / L<(0.2-0.4)$, and vice versa streams towards the cavity lid when $x / L>(0.2-0.4)$. The specified distance $x / L$ limits indicate that the centre of the main vortex changes its position, which corresponds to the minimum velocity.

A similar situation is observed in the secondary vortex zone taking into account the fact that the rotation direction is opposite to the rotation direction of the main vortex.

In all cases, velocity differences between flow directed towards cavity bottom and its lid in the same measuring plane are registered. Also, primary and secondary vortices structures and maximum velocities location changes are observed over the whole depth of the cavity. This can be explained by transversal overflows existing in the cavity, which lead to the formation of three-dimensional flow.

\section{Pulsatile flow over open cavity}

Measurements on pulsatile flow conditions were performed in the laminar flow regime at $\operatorname{Re}=100-1000$ and on different sine wave frequencies from 10 to $40 \mathrm{~Hz}$. Since all velocity profiles at the investigated Re number range are similar in the middle plane of the cavity, only the results obtained at $\mathrm{Re}=1000$ are presented in Fig. 5. A little velocity increase over the primary 


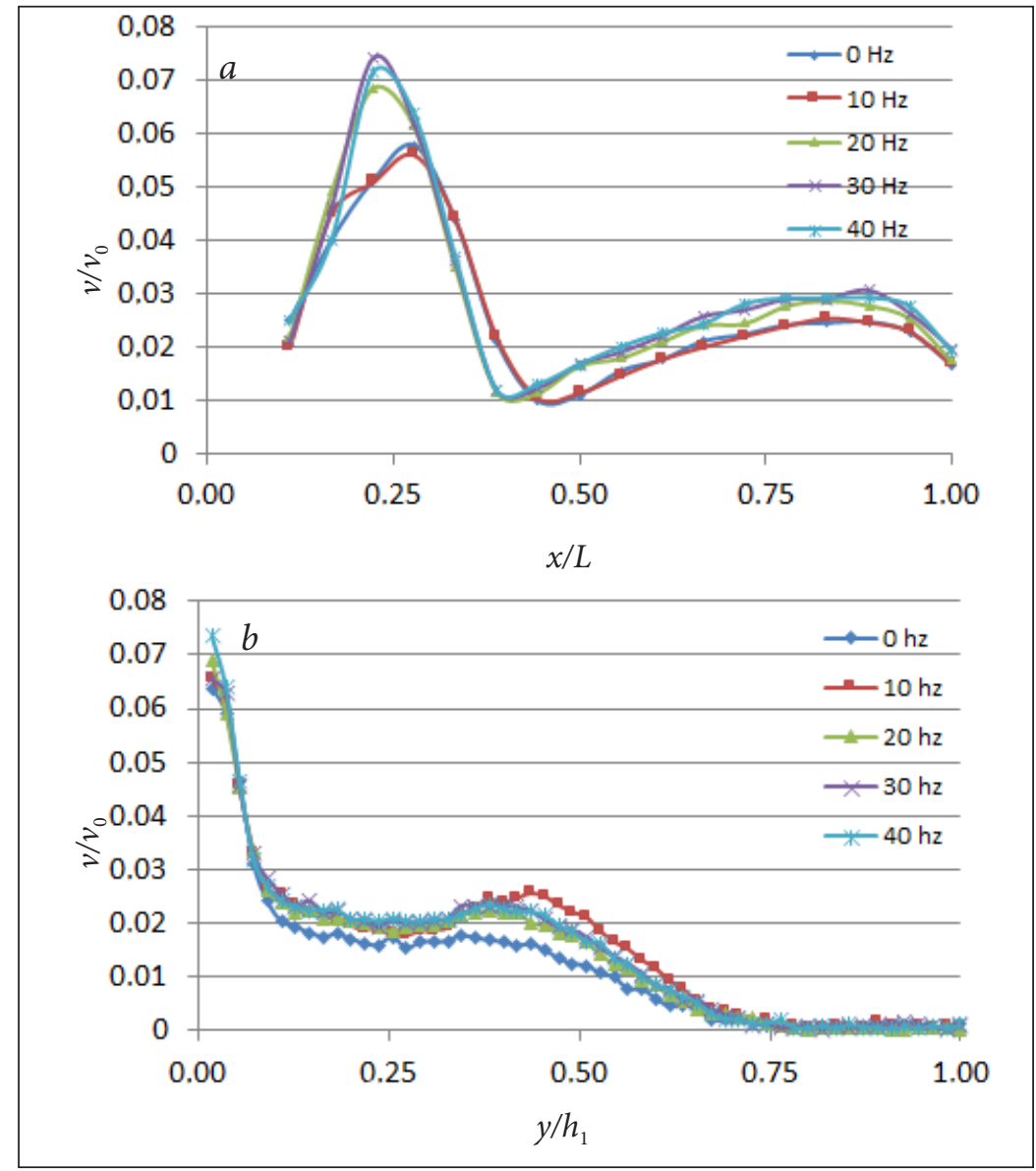

Fig. 5. Relative velocity values ( $a$ ) of primary vortex and $(b)$ along the depth of the cavity in the axial plane at $\mathrm{Re}=1000$ and under different pulse conditions

vortex can be observed on flow leaving the cavity on a higher pulse frequency. As can be seen from Fig. 5b, no significant influence on velocity distribution is observed along the cavity.

More measurements were performed at different planes of the cavity in steps of $40 \mu \mathrm{m}$ in both sides of the axial plane. The created 3D surface maps of velocity profile in cavity structure at $\mathrm{Re}=100$ and $\mathrm{Re}=1000$ are presented in Fig. $6 \mathrm{a}$ and $6 \mathrm{~b}$, respectively. White arrows indicate velocity direction towards the bottom (up) and the lid (down) of the cavity, and the black arrow indicates direction of the main flow in the channel. The left part of the graph corresponds to the forward-facing wall where flow enters the cavity, and the right part corresponds to the backward-facing wall where flow leaves the cavity and meets the main flow in the channel. Thus, the middle part, where velocity is the smallest along the height of the cavity, corre- sponds to vortex centre. As can be seen, distribution of velocity entering the cavity is symmetric at $R e=100$. In this case, velocity minimum is observed at the axial plane of the cavity, which divides the vortex into two same size parts. Each part keeps the structure of vortex. At $\operatorname{Re}=1000$, the profile of velocity entering the cavity is asymmetric over the height of the cavity with a drop of velocity near one of cavity walls and significant maximum in the axial plane. In this case, pulsatile flow causes the flattening of velocity profile, which is observed at the most part of flow entering the cavity and across the whole area near the forward-facing wall. Compared both profiles it can be seen that vortex structure is smoother at $\mathrm{Re}=1000$. At higher Re number, secondary flows in the corners of square cross-section cavity can be suppressed by unsteady flow. This leads to the flattening of velocity profile near the side walls of the cavity. 


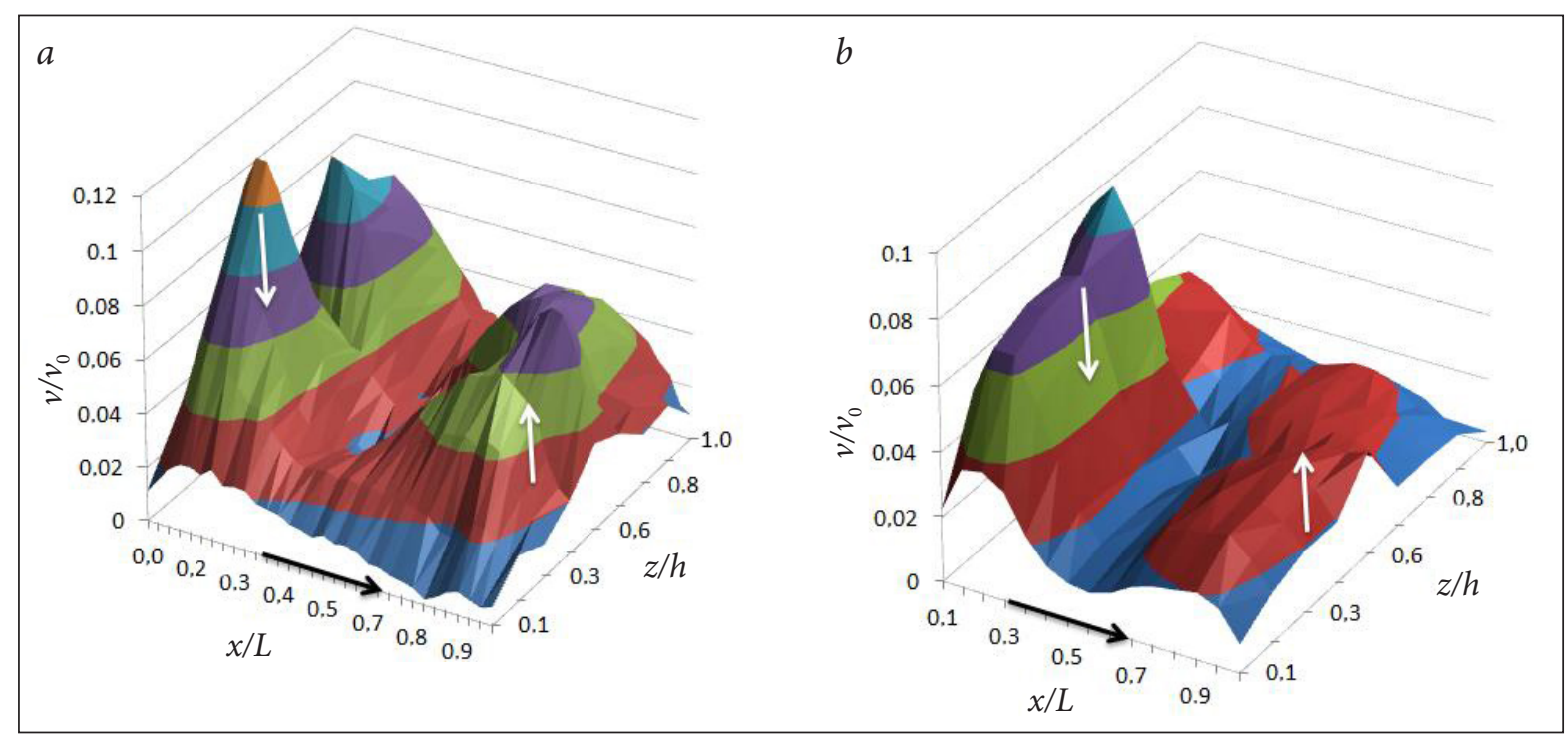

Fig. 6. Three-dimensional velocity profiles across primary vortex at $(a) \mathrm{Re}=100$ and $(b) \mathrm{Re}=1000$ and pulsatile sine wave frequency $40 \mathrm{~Hz}$

\section{CONCLUSIONS}

In this article, the flow structure in an open-type cavity under stationary and pulsatile flow conditions was investigated. Flow regime in the main channel changed from laminar to fully turbulent. At stationary and pulsatile flow conditions, velocity differences near backward-facing and forward-facing walls were registered. Also, change of vortex structure and location of maximum velocity was observed at different measurement planes. These flow structure differences over the height of the cavity lead to a conclusion that transversal flows exist in the cavity and flow structure is three-dimensional in laminar and turbulent flow regimes. Under different pulsatile flow conditions, there are no significant changes of flow structure in the axial plane. Changes of velocity profiles are observed at transversal planes away from axial planes of the cavity. With increasing Reynolds number, velocity distribution in pulsating flow flattens out. It means that disturbed flow in the channel accelerates the formation of a stable flow structure in the cavity.

Received 5 April 2016 Accepted 15 May 2016

\section{References}

1. Anderson P. D., Galaktionov O. S., Peters G. W. M., van derVosse F. N., Meijer H. E. H. Cha- otic fluid mixing in non-quasi-static time-periodic cavity flows. International Journal of Heat and Fluid Flow. 2000. Vol. 21. No. 2. P. 176-185.

2. Velazquez A., Arias J. R., Mendez B. Laminar heat transfer enhancement downstream of a backward facing step by using a pulsating flow. International Journal of Heat and Mass Transfer. 2008. Vol. 51. No. 7. P. 2075-2089.

3. Lieber B. B., Livescu V., Hopkins L. N., Wakhloo A. K. Particle image velocimetry assessment of stent design influence on intra-aneurysmal flow. Annals of Biomedical Engineering. 2002. Vol. 30. No. 6. P. 768-777.

4. Cheng M., Hung K. C. Vortex structure of steady flow in a rectangular cavity. Computers and Fluids. 2006. Vol. 35. No. 10. P. 1046-1062.

5. Faure T. M., Adrianos P., Lusseyran F., Pastur L. Visualizations of the flow inside an open cavity at medium range Reynolds numbers. Experiments in Fluids. 2007. Vol. 42. No. 2. P. 169-184.

6. Faure T. M., Defrasne A., Lusseyran F., Pastur L. Flow instabilities development inside an open cavity. 13th International Symposium on Flow Visualization. 2008.

7. Beaudoin J-F., Cadot O., Aider J.-L., Wesfreid J.-E. Three-dimensional stationary flow over a backward-facing step. European Journal of Mechanics - B/Fluids. 2004. Vol. 23. No. 1. P. 147-155. 
Paulius Vilkinis, Mantas Valantinavičius, Nerijus Pedišius

SRAUTO STRUKTŪROS ATVIROJO TIPO KAVERNOJE TYRIMAS ESANT STACIONARIAM IR PULSUOJANČIAM TEKE்JIMO REŽIMAMS

\section{Santrauka}

Žinios apie srauto struktūrą struktūrizuotose kanaluose yra itin svarbios sprendžiant su srautų dinamika susijusius uždavinius. Jos gali būti panaudotos intensifikuojant šilumos mainus bei skysčių maišymąsi kanaluose ir mikroelektromechaninèse sistemose (MEMS). Srauto dinamikos tyrimai atlikti mikrokavenose gali būti panaudoti sprendžiant su aneurizmų susidarymu kraujagyslèse susijusias problemas. Šiame darbe mikrosrautų vizualizacijos sistema buvo panaudota ištirti vandens srautą atviro tipo mikrokavernoje. Tiriamos mikrokavernos, viena priešais kitą, ittaisytos tiesaus mikrokanalo vidurineje dalyje. Matavimai buvo atlie- kami skirtingose plokštumose per visą kavernos aukštị, Reinoldso skaičiui kintant nuo 100 iki 3 000, t. y. kanale esant laminariniam, pereinamajam ir turbulentiniam režimams. Taip pat matavimai atlikti srautui kanale tekant stacionariai ir pulsuojant tam tikru dažniu. Eksperimentiniai greičio profilių formos kitimo rezultatai skirtingose kavernos plokštumose parodè, kad srautas atvirojo tipo kavernoje yra trimatis. Pagal greičio profilių kitimą galima spręsti apie kavernoje esantị tekejjimą skersine kryptimi. Taip pat greičio profilio forma kavernoje priklauso nuo tekejimo režimo ir pulsacijos charakteristikų. Esant pulsuojančiam tekejjimui, greičio profilio išsilyginimas pasiekiamas ties mažesniu Reinoldso skaičiumi nei stacionaraus tekejjimo atveju. Tai leidžia teigti, kad srauto sutrikdymas kanale leidžia greičiau pasiekti stabilią tekejjimo struktūrą kavernoje.

Raktažodžiai: mikrosrautai, tekejjimas mikrokanale, mikrosrautų vizualizacijos sistema, atvirojo tipo mikrokaverna 